\title{
Should Robots Pay TaXes? Tax Policy in the Age OF AUTOMATION
}

\author{
RYAN ABBOTT ${ }^{*}$ AND BRET BOGENSCHNEIDER ${ }^{T}$
}

\begin{abstract}
Existing technologies can already automate most work functions, and the cost of these technologies is decreasing at a time when human labor costs are increasing. This, combined with ongoing advances in computing, artificial intelligence, and robotics, has led experts to predict that automation will lead to significant job losses and worsening income inequality. Policy makers are actively debating how to deal with these problems, with most proposals focusing on investing in education to train workers in new job types, or investing in social benefits to distribute the gains of automation.
\end{abstract}

The importance of tax policy has been neglected in this debate, which is unfortunate because such policies are critically important. The tax system incentivizes automation even in cases where it is not otherwise efficient. That is because the vast majority of tax revenue is now derived from labor income, so firms avoid taxes by eliminating employees. More importantly, when a machine replaces a person, the government loses a substantial amount of tax revenuepotentially trillions of dollars a year in the aggregate. All of this is the unintended result of a system designed to tax labor rather than capital. Such a system no longer works once the labor is capital. Robots are not good taxpayers.

We argue that existing tax policies must be changed. The system should be at least "neutral" as between robot and human workers, and automation should not be allowed to reduce tax revenue. This could be achieved by disallowing corporate tax deductions for automated workers, creating an "automation tax" which mirrors existing unemployment schemes, granting offsetting tax preferences for human workers, levying a corporate self-employment tax, or increasing the corporate tax rate. We argue the ideal solution may be a combination of these proposals.

\footnotetext{
* Professor of Law and Health Sciences, University of Surrey, School of Law and Adjunct Assistant Professor of Medicine at the David Geffen School of Medicine at University of California, Los Angeles.

T Senior Lecturer (Assoc. Professor), Finance Law \& Ethics, University of Surrey, School of Law.
} 


\section{INTRODUCTION}

An automation revolution is underway. ${ }^{1}$ Current technologies can already mechanize most work activities, and the cost of these technologies is decreasing at a time when human labor costs are increasing. ${ }^{2}$ On top of that, ongoing and exponential improvements in computing, artificial intelligence, and robotics are permitting automation in an ever increasing number of fields. ${ }^{3}$ As a result, academic and industry experts are widely predicting that automation will result in substantial "technological unemployment" in the near future. ${ }^{4}$ For instance, the McKinsey Global

1 Bank of America Merrill Lynch, Robot Revolution-Global Robot \& AI Primer (2015) <www.bofaml.com/content/dam/boamlimages/documents/PDFs/robotics_and_ai_condensed_primer.pdf > ("The pace of disruptive technological innovation has gone from linear to parabolic in recent years. Penetration of robots and artificial intelligence (AI) has hit every industry sector, and has become an integral part of our daily lives. Technology has also expanded beyond routine work, and moved into complex problem-solving, and replicating human perception, tasks that only people were capable of."). "The word 'automation' was coined by Delmar S. Harder, then executive vice president of the Ford Motor Co., in attempting to describe the latest kind of assembly line technique involving engineblock transfer machines then being installed at Ford's River Rouge and Cleveland plants." United States Congress. Senate. Committee on Labor and Public Welfare. Nation's manpower revolution. Hearings before the Subcommittee on Employment and Manpower of the Committee on Labor and Public Welfare, United States Senate, Eighty-eighth Congress, first session, relating to the training and utilization of the manpower sources of the Nation Part 5, at 1659 (1963); for a definition of the term "automation" see: Meg Leta Jones, The Ironies of Automation Law: Tying Policy Knots with Fair Automation Practices Principles, 18 VAND. J. ENT. \& TECH. L. 77, 84 (2015) ("Broadly, automation includes all the ways computers and machines help people perform tasks more quickly, accurately, and efficiently. The term "automation" refers to: (1) the mechanization and integration of the sensing of environmental variables through artificial sensors, (2) data processing and decision making by computers, and (3) mechanical action by devices that apply forces on the environment or information action through communication to people of information processed. The term encompasses open-loop operations and closed-loop control as well as intelligent systems.") (citations omitted); One of the most cited studies on technological unemployment claims that $47 \%$ of American jobs are at high risk of loss due to automation. Carl Benedikt Frey and Michael A. Osborne, The Future of Employment: How susceptible are Jobs to Computerisation? Oxford Martin Programme on Technology and Employment, Sept, 2013 (reporting that 47\% of American workers are at high risk of automation and stating that, "recent developments in machine learning will put a substantial share of employment, across a wide range of occupations, at risk in the near future.").

2 JAMES MANYIKA, ET AL., HARNESSING AUTOMATION FOR A FUTURE THAT WORKS (2013) <http://www.mckinsey.com/global-themes/digital-disruption/harnessing-automation-for-a-future-that-works >

(predicting that fewer than 5 percent of occupations could be entirely automated with existing technologies); see also Carl Benedikt Frey \& Michael A. Osborne, The Future of Employment: How Susceptible Are Jobs to Computerisation? 41 (2013) <www.oxfordmartin.ox.ac.uk/downloads/academic/future-of-employment.pdf.>.

${ }^{3}$ For examples of automation in white-collar and professional settings, see, e.g., Roger Parloff, Why Deep Learning is Already Changing Your Life, Fortune, Sept. 28, 2016, http://fortune.com/ai-artificial-intelligence-deep-machinelearning/. Of particular concern to future attorneys, artificial intelligence is already automating work functions in the legal services industry. See, e.g., Jane Croft, Legal firms unleash office automatons, Financial Times, May 16, 2016, <https://www.ft.com/content/19807d3e-1765-11e6-9d98-00386a18e39d> (discussing various software programs that can outperform attorneys and paralegals in document review). $C f$. Dana Remus and Frank S. Levy, Can Robots Be Lawyers? Computers, Lawyers, and the Practice of Law, Dec. 30, 2015, <http://dx.doi.org/10.2139/ssrn.2701092> (arguing that artificial intelligence will refocus rather than replace attorneys).

${ }^{4}$ Supra note 1. In the 1930s, the economist John Maynard Keynes popularized the term "technological unemployment" to refer to "unemployment due to our discovery of means of economising the use of labour outrunning the pace at which we can find new uses for labour." John Maynard Keynes, ESSAYS IN PERSUASION (1930) at 358-373. 
Institute has claimed the disruption caused by artificial intelligence will, "happ[en] ten times faster and at 300 times the scale, or roughly 3,000 times the impact" of the Industrial Revolution. ${ }^{5}$ We are entering an era in which the combined impact of technological improvements in many different areas is going to be profoundly transformative-and disruptive. ${ }^{6}$

Automation has the potential to create widespread benefits. Not only will automation increase productivity, it will improve safety and lead to new scientific breakthroughs. ${ }^{7}$ But without oversight, automation will also exacerbate unemployment and economic inequality. ${ }^{8}$ Even if workers rendered technologically unemployed are able to transition to new jobs, as has been the case during previous eras of rapid change, there will still be significant short term disruptions. Moreover, many experts are predicting that today's technological advances are different in kind from those of the past, and that large scale permanent increases in unemployment are inevitable. ${ }^{9}$ In 1990, the three largest companies in Detroit with a combined market capitalization of $\$ 36$ billion

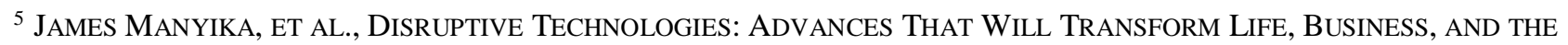
GLOBAL ECONOMY (2013) (predicting also $\$ 6$ trillion in economic impact by 2025 from advanced robotics, 3D printing and autonomous vehicles).

6 See, e.g., Herring Kagermann, et al., Recommendations for Implementing the Strategic Initiative INDUSTRIE 4.0: FINAL REPORT OF THE INDUSTRIE 4.0 WORKING GROUP (2013) at 5 ("The first three industrial revolutions came about as a result of mechanisation, electricity and IT. Now, the introduction of the Internet of Things and Services into the manufacturing environment is ushering in a fourth industrial revolution."); see also, Vernor Vinge, The Coming Technological Singularity: How to Survive in the Post-Human Era (1993) <wwwrohan.sdsu.edu/faculty/vinge/misc/singularity.html> (the article which coined the term "Singularity" to refer to the argument that, "we are on the edge of change comparable to the rise of human life on Earth. The precise cause of this change is the imminent creation by technology of entities with greater than human intelligence.")

${ }^{7}$ See, e.g., Ryan Abbott, The Reasonable Computer: Disrupting the Paradigm of Tort Liability (2016)

$<$ https://ssrn.com/abstract=2877380 > (discussing the potential of automation to result in substantial safety benefits, for instance in the transportation industry); see also, Ryan Abbott, I Think, Therefore I Invent: Creative Computers and the Future of Patent Law. 1079 B. C. Law Rev. 1083-1091 (2016) (discussing examples in which artificial intelligence has generated patentable subject matter under circumstances in which the computer rather than a person has qualified for inventorship).

${ }^{8}$ Executive Office of the President National Science and Technological Committee on Technology, PREPARING FOR THE FUTURE OF ARTIFICIAL INTELLIGENCE (2016) at 2.

9 Klaus Schwab and Richard Samans, The Future of Jobs, Preface (2016) <reports.weforum.org/future-of-jobs2016/preface/>; see also Brian Dorini, The End of Work: The Decline of the Global Labor Force and the Dawn of the Post-Market Era, 9 HARV. J.L. \& TECH. 231 (1995) reviewing Jeremy Rifkin, THE END OF Work: THE DECLINE OF THE Global LABOR ForCE AND THE DAWN OF THE POST-MARKET ERA (1995) 233 ("The ranks of the unemployed are swelling with former service sector workers, such as secretaries, receptionists, clerks, and cashiers. These workers are being replaced by what Rifkin calls the silicon-collar workforce: answering machines, scanners, voice and handwriting recognition devices, electronic mail, and inventory control and monitoring devices.") Id at 136-43.
} 
employed 1.2 million workers. ${ }^{10}$ In 2014, the three largest companies in Silicon Valley with a combined market capitalization of $\$ 1.09$ trillion employed 137,000 workers. $^{11}$

These are not new problems. ${ }^{12}$ In 1962, President Kennedy stated, "I regard it as the major domestic challenge, really, of the sixties, to maintain full employment at a time when automation, of course, is replacing men." ${ }^{13}$ His solution was to pass the nation's first and most sweeping federal program to train workers unemployed due to technological advances. ${ }^{14}$ More recently, in December, 2016, the Executive Office of the President issued a report which outlined a threepronged policy response to automation and artificial intelligence (AI): namely, to (i) "[i]nvest in and develop AI for its many benefits”, (ii) “[e]ducate and train Americans for jobs of the future”, and, (iii) "[a]id workers in the transition and empower workers to ensure broadly shared growth". ${ }^{15}$ These and other proposals for dealing with automation have focused on improving education and improving social benefit systems. Concerns about technological unemployment have even breathed new life into an old social benefit proposal—guaranteed minimum income. ${ }^{16}$ That could involve the government's making fixed payments to each of its citizens regardless of their circumstances. ${ }^{17}$

\footnotetext{
${ }^{10}$ M. Chui and J. Manyika, Digital era brings hyperscale challenges. Financial Times Aug. 13, 2014.

${ }^{11} \mathrm{Id}$.

12 See generally, Forbes, John Douglas, SOME EVIDENCES OF TECHNOLOGICAL UNEMPLOYMENT IN ANCIENT ATHENS AND ROME (1932). For instance, the Roman Emperor Vespasian once refused to use a labor saving transportation machine, famously stating, "You must allow my poor hauliers to earn their bread." Steve Welch, The real political divide is education, Tech Crunch, Dec. 30, 2016, <https://techcrunch.com/2016/12/30/the-real-political-divide-iseducation/>.

${ }^{13}$ John F. Kennedy, Public Papers of the Presidents of the United States, The President's NeWs CONFERENCE OF FEBRUARY 14, 1962 (1962) at 135.

${ }^{14}$ Gladys Roth Kremen, MDTA: The Origins of the Manpower Development and Training Act of 1962, United States Department of Labor (1974) <www.dol.gov/general/aboutdol/history/mono-mdtatext> (describing the law's origins). Also of note, a year earlier, the Office of Automation and Manpower was created at the Department of Labor to anticipate technological change and create occupational guidance. General Order, April 20, 1961, Hist. Ofce.; Press Release, April 20, 1961, Hist. Ofce. For extensive reviews of automation issues in the 1960s, see generally, Office of Manpower. James L. Sundquist, Politics and Policy: the Eisenhower, Kennedy, and Johnson Years (Washington, DC: The Brookings Institution, 1968) p. 77.

${ }^{15}$ Executive Office of the President, Artificial InTElligence, AutOMATiOn, AND THE ECONOMY (2016) at 3.

${ }^{16}$ It was proposed during the Industrial Revolution by Charles Fourier, and then later Joseph Charlier, before being adopted by John Stuart Mill. Philippe Van Parijs, A Basic Income for All, Boston Review (2000) <bostonreview.net/forum/ubi-van-parijs>. Mill proposed, "a certain minimum is first assigned for the subsistence of every member of the community, whether capable or not of labour." Id.

17 Stevens at 373 ("One of the most commonly considered government payout schemes is what is referred to as a basic
} 
Both education and social benefit reforms to deal with automation would require significant financial support.

While there has been a lively public discourse on technological unemployment and income disparity, the automation debate has historically ignored the issue of taxation. That has very recently started to change. On February 16, 2017, the European Parliament rejected a proposal to impose a "robot tax" on owners to fund support for displaced workers, citing concerns of stifling innovation. ${ }^{18}$ The next day, Bill Gates stated that he thought government should tax companies' use of robots to slow the spread of automation and to fund other types of employment. ${ }^{19}$ While these are promising developments, the current discourse has not adequately appreciated the importance of tax policies on automation.

The current taxation system encourages automation by providing employers with preferential tax treatment for robot workers. Automation allows firms to avoid employee and employer wage taxes levied by Federal, state, and local taxing authorities. It also permits firms to claim accelerated tax depreciation on capital costs for automated workers, and it creates a variety of indirect incentives for machine workers. All of this is the unintended result of a tax system designed to tax labor rather than capital. Tax policies may thus result in automation in some cases in which a firm would otherwise choose a human worker.

\footnotetext{
income guarantee. Generally speaking, Basic Income Guarantee is a monetary government-backed and issued guarantee such that all adults have access to an amount of money necessary to meet basic needs."). President Richard Nixon also once proposed a guaranteed basic income of about $\$ 10,000$ in today's dollars for families of four. This proposal, the Family Assistance Plan, passed through the House before it was voted down by Senate Democrats. Whitney Mallett, The Town Where Everyone Got Free Money, Motherboard, Feb. 4, 2015 <motherboard.vice.com/read/the-mincomeexperiment-dauphin>.

${ }^{18}$ Reuters, European parliament calls for robot law, rejects robot tax. Feb 16, 2017.

${ }^{19}$ Kevin Delany, The robot that takes your job should pay taxes, says Bill Gates, Quartz, Feb. 17, 2017 ("Exactly how you'd do it, measure it, you know, it's interesting for people to start talking about now.").
} 
Even more concerning, automation significantly reduces the government's tax revenue since most tax revenue comes from labor income. ${ }^{20}$ When firms replace employees with machines, the government loses revenue. As a very rough estimate, the revenue loss can be estimated by multiplying an effective tax rate by the gross salary loss due to automation. In January 2017 , the McKinsey Global Institute claimed that about half of current work activities could be automated using currently demonstrated technologies, which would eliminate $\$ 2.7$ trillion in annual wages. Workers pay high effective tax rates ranging from $25 \%$ to $55 \%$ when all tax types are taken into account. ${ }^{21}$ This suggests that worker automation could result in trillions of dollars lost per year in tax revenue at various levels of government. ${ }^{22}$

In the United States and most other developed nations, the bulk of taxes are currently remitted by workers either through wage withholding, income taxation of labor income, or indirect taxation of workers as consumers. ${ }^{23}$ Since robots are not subject to these types of tax regimes, automation reduces the overall tax base. Robots are simply not taxpayers, at least not to the same extent as human workers. If all workers were to be replaced by machines tomorrow, most of the tax base would immediately disappear. As a matter of taxation, automated workers represent a type of

\footnotetext{
${ }^{20}$ Office of Management and Budget (OMB), The Budget for Fiscal Year 2015, Historical Tables, p. 32-33 $<$ www.whitehouse.gov/sites/default/files/omb/budget/fy2015/assets/hist.pdf $>$; Internal Revenue Service, Data Book Statistics <www.irs.gov/uac/SOI-Tax-Stats-Collections-and-Refunds,-by-Type-of-Tax-IRS-Data-Book-Table-1>; Congressional Budget Office, The Distribution of Household Income and Federal Taxes, 2010 (December 2013) www.cbo.gov; see also Lester Snyder \& Marianne Gallegos, Redefining the Role of the Federal Income Tax: Taking the Tax Law "Private" Through the Flat Tax and Other Consumption Taxes, 13 Am. J. Tax Pol'y 1 (1996).

${ }^{21}$ Bret N. Bogenschneider, The Effective Tax Rate of U.S. Persons by Income Level, 145 TAX NOTES 117 (2014).

22 JAMES MANYIKA, ET AL., HARNESSING AUTOMATION FOR A FUTURE THAT WORKS (2013) (predicting that fewer than 5 percent of occupations could be entirely automated with existing technologies); see also Carl Benedikt Frey \& Michael A. Osborne, The Future of Employment: How Susceptible Are Jobs to Computerisation? 41 (2013) <www.oxfordmartin.ox.ac.uk/downloads/academic/future-of-employment.pdf〉.

${ }^{23}$ OECD Revenue statistics <stats.oecd.org/Index.aspx?DataSetCode=REV>; see also OECD Release of April 11, 2017 http://www.oecd.org/tax/taxing-wages-20725124.htm (calculating a "tax wedge" of an average of 36\% as the level of wage taxation minus a hypothetical amount of value received by working families). The OECD's tax policy analysis of wage taxation is constrained by the lack of a calculation of the "tax wedge" for other types of taxation, such as corporate taxation, thus rendering the policy analysis only a comparison of apples to oranges. For example, corporate taxpayers also received value in the form of government contracts and so forth and the OECD does not attempt to calculate these benefits. Furthermore, the term "tax wedge" is a misnomer as that term normally refers to a deadweight loss of income taxation and not an offset for certain types of taxation in the form of benefits received by a select group of taxpayers.
} 
capital investment, and capital income is taxed at much lower rates than labor income. ${ }^{24}$ This is not accidental; it is based on the historic belief that the taxation of labor income is more efficient than the taxation of capital income. This concept is discussed in tax policy analysis as the "tax incidence" of capital taxation. ${ }^{25}$

Tax is thus critically important to the automation debate. Tax policies should not encourage automation unless it is part of a deliberate strategy based on sound public policy. We believe the solution is to adjust the tax system to be at least neutral as between robot and human workers. ${ }^{26}$ More ambitiously, changes to tax policies are necessary to account for the loss of government tax revenue due to automation. This is particularly critical because the education and social benefit reform necessitated by automation will only be possible with more, not less, tax revenue.

This article outlines several potential tax policy solutions to address the automation revolution. Tax "neutrality" between human and automated workers could be achieved by disallowing corporate tax deductions for automated workers, creating an "automation tax" which mirrors existing unemployment schemes, granting offsetting tax preferences for human workers, levying a corporate self-employment tax, and increasing the corporate tax rate. The advantage of tax "neutrality" as between human and automated workers is that it permits the marketplace to adjust without tax distortions. Firms may then elect to automate if it will be more efficient without

\footnotetext{
${ }^{24}$ The term "capital taxation" refers here to corporate income taxation. For a comparison of effective tax rates between US and EU multinationals see: Reuven Avi-Yonah, R. \& Y. Lahav, The Effective Tax Rate of the Largest U.S. and EU Multinationals, 65 TAX LAW REV. 375 (2012).

${ }^{25}$ In a strange twist of economic theory, the ultimate cost of wage taxation paid by workders is generally thought to be borne by capital. See Arnold Harberger, Tax Policy in a Small, Open Developing Economy, in "The Economics of the Caribbean Basin" (M. B. Connolly ed., 1985); For the extension of the 'small open economy' model beyond the small open economy context see A. Lans Bovenberg, Capital Income Taxation in Growing Open Economies, (1986) 31 J. POL. ECON. 347; Anne Sibert, Taxing Capital in a Large, Open Economy, 41 J. Pol. Econ. 297 (1990); Alan Auerbach, Who Bears the Corporate Tax: A Review of What We Know, 20 TAX POLICY \& ECONOMY 1 (2006).

${ }^{26}$ Meisel at 226 ("There are other alternatives using the tax code. One option suggested by Martin Ford in The Lights in the Tunnel is modification of the payroll tax, a tax that discourages hiring people and encourages automation since it makes the use of people more expensive. He suggests a reform of the tax system where we get away from taxing based on workers to reduce the disincentive to hiring.") citing Martin Ford, The Lights in the Tunnel: Automation, Accelerating Technology and the Economy of the Future (New York: Createspace, 2009).
} 
taking taxes into account. Since the current tax system favors automated workers, a move toward a "neutral" tax system could increase the appeal of human workers. Policy solutions could even be implemented to make human workers more appealing than machines in terms of tax costs and benefits to the extent policy makers choose to discourage automation.

The remainder of this article is divided into three parts. Part II discusses the phenomenon of automation and provides historical background on efforts to deal with its harmful effects. Part III analyzes current tax policies and contends that they promote automation even where it would not otherwise be efficient. Finally, Part IV argues that changes to tax policy are needed to prevent the unintended consequences of encouraging automation and to offset the government's loss of tax revenue. We provide several potential solutions for achieving these goals, and argue the ideal solution is a mix of changes to tax policy.

The increased tax revenue from our proposal could be used to provide improved education and training for workers rendered unemployed by robots and computers. Should the pessimistic prediction of a near future with substantially increased unemployment due to automation manifest, these taxes could also support social benefit programs such as a guaranteed minimum income. Automation will likely generate more wealth than has ever been possible. It should not come at the expense of the most vulnerable.

\section{THE PROBLEM WITH AUTOMATION}

\section{Automation is Coming}

Experts are widely predicting that automation is going to have a substantial impact on employment even in the near term. Bank of America Merrill Lynch argues that by 2025, AI may eliminate $\$ 9$ trillion in employment costs by automating knowledge work. ${ }^{27} \mathrm{~A}$ report by the World

27 Bank of America Merrill Lynch, Robot Revolution-Global Robot \& AI Primer (2015) 
Economic Forum estimates that automation could result in the net loss of 5.1 million jobs by 2020. ${ }^{28}$ The consulting firm Deloitte claims that 35 percent of jobs in the United Kingdom are at high risk of redundancy due to automation in the next 10 to 20 years. ${ }^{29}$ The McKinsey Global Institute has stated that 51 percent of existing work activities could be automated using existing technologies. ${ }^{30}$ This is due to a combination of factors: improvements in automation technologies, decreased costs for such technologies, and increased labor costs. ${ }^{31}$ Whereas it was previously possible to automate a large number of work processes, it has now become practicable. As automation technologies continue to both improve and decrease in cost, it is difficult to think of work functions that will not eventually be susceptible to automation. ${ }^{32}$

\section{The Good}

Automation increases productivity which generates value and creates wealth. ${ }^{33}$ Partly due to technological advances and automation, the U.S. Gross Domestic Product (GDP) has steadily risen

\footnotetext{
<www.bofaml.com/content/dam/boamlimages/documents/PDFs/robotics_and_ai_condensed_primer.pdf> (noting also that AI will yield \$14-33 trillion in annual economic impact)

28 See, Klaus Schwab and Richard Samans, The Future of Jobs, Preface (2016) <reports.weforum.org/future-of-jobs2016/preface/>.

29 Deloitte, Agiletown: the relentless march of technology and London's response (2014) <www2.deloitte.com/content/dam/Deloitte/uk/Documents/uk-futures/london-futures-agiletown.pdf>

30 JAMES MANYIKA, ET AL., HARNESSING AUTOMATION FOR A FUTURE THAT WORKS (2013) <http://www.mckinsey.com/global-themes/digital-disruption/harnessing-automation-for-a-future-that-works>; see also Carl Benedikt Frey \& Michael A. Osborne, The Future of Employment: How Susceptible Are Jobs to Computerisation? 41 (2013) <www.oxfordmartin.ox.ac.uk/downloads/academic/future-of-employment.pdf.>.

${ }^{31}$ See supra notes 27-30.

${ }^{32}$ See, Ryan Abbott, Hal the Inventor: Big Data and its Use by Artificial Intelligence. In Big Data is Not a Monolith, MIT Press (Hamid Ekbia, et al., eds.) (2016) at 188-191 (noting the ways in which automation technologies could replace workers in the pharmaceutical sciences).

${ }_{33}$ See generally, Joel Mokyr, Chris Vickers, and Nicolas L. Ziebarth, The History of Technological Anxiety and the Future of Economic Growth: Is This Time Different? 29(3) The Journal of Economic Perspectives 31-50 (2015)
} 
from $\$ 1.37$ trillion in 1960 to $\$ 73.5$ trillion in $2015 .{ }^{34}$ Despite academic criticism, GDP has remained the dominant economic indicator of welfare and standard of living for half a century. ${ }^{35}$

Automation can also create new jobs. ${ }^{36}$ Human workers may be needed to build and maintain automation technologies. Automation may free up capital for investments in new enterprises, result in the creation of new products, or decrease production costs for existing products which may result in lower prices and thus greater consumer demand, all of which may increase employment. Technological advances have also upgraded the labor force: automation has historically reduced the need for unskilled workers but increased the need for skilled workers. ${ }^{37}$ For instance, some of today's most in-demand occupations did not exist even five years ago. ${ }^{38}$

\section{The Bad}

Automation can cause under- and un-employment. While worker productivity has risen robustly since 2000 , employment has stagnated. This may be due in part to technological advances. ${ }^{39}$ When McDonald's introduces computer cashiers, the company saves money and consumers may enjoy lower prices. ${ }^{40}$ But human cashiers now find themselves in a more

\footnotetext{
${ }^{34}$ The World Bank, GDP (current US\$), World Bank national accounts data, and OECD National Accounts data files <data.worldbank.org/indicator/NY.GDP.MKTP.CD>; see also, Carl Benedikt Frey and Michael Osborne, TECHNOLOGY AT WORK: THE FUTURE OF INNOVATION AND EMPLOYMENT (2015) at 11 <www.oxfordmartin.ox.ac.uk/downloads/reports/Citi_GPS_Technology_Work.pdf>.

${ }^{35}$ See, e.g., Jeroen C.J.M. van den Bergh, The GDP paradox, 30(2) Journal of Economic Psychology 117-135, 117 (2009) ("Gross domestic product (GDP) is the monetary, market value of all final goods and services produced in a country over a period of a year. The real GDP per capita (corrected for inflation) is generally used as the core indicator in judging the position of the economy of a country over time or relative to that of other countries. The GDP is thus implicity, and often even explicitly, identified with social welfare-witness the common substituting phrase 'standard of living'. . . For over half a century now, the GDP (per capita) has been severely criticized as not adequately capturing human welfare and progress. All the same, the GDP has maintained a firm position as a dominant economic indicator..."). ${ }^{36}$ The following arguments were referred to as "compensation theory" by Karl Marx, who argued none of these effects were guaranteed. Jon Elster, Karl Marx A Reader (1986) at 81.

${ }^{37}$ U.S. Congress, Joint Economic Committee, Automation and Technological Change, Hearing before a subcommittee (Washington, DC: GPO, 1955) p. 14.

${ }^{38}$ See, Klaus Schwab and Richard Samans, The Future of Jobs, Preface (2016) <reports.weforum.org/future-of-jobs2016/preface/>.

${ }^{39}$ See, e.g., Erik Brynjolfsson and Andrew McAfee, The Second Machine Age: Work, Progress, And Prosperity IN A TIME OF BRILLIANT TECHNOLOGIES (2014) at 139.

${ }^{40}$ See, Ted Goodman, Fight for \$15? McDonald's To Place Automated Ordering Stations At All US Locations, The Daily
} 
competitive labor market. The enhanced competition may result in lower wages, less favorable employment terms, fewer working hours, reduced hiring, or layoffs. ${ }^{41}$ As the former CEO of McDonald's USA famously quipped, "it's cheaper to buy a $\$ 35,000$ robotic arm than it is to hire an employee who's inefficient making \$15 an hour bagging French fries..."42 McDonald's is now expanding its use of automated cashiers throughout the United States and in other countries. ${ }^{43}$

Also, while automation generates wealth, it does so unevenly. Over the past 25 years, partly due to automation technologies, the income share of the top $0.1 \%$ has increased substantially. ${ }^{44}$ Productivity increases have outpaced wage increases, and median household income has held steady even as the GDP has gradually risen. ${ }^{45}$ Increased automation is likely to accelerate this trend. The White House Council of Economic Advisors (CEA) has predicted that future automation

Caller, Nov. 18, 2016, <dailycaller.com/2016/11/18/fight-for-15-mcdonalds-to-place-automated-ordering-stations-atall-us-locations/>. Standard economic principles suggest that in a competitive market lower business costs will result in lower consumer prices. See, e.g., Arthur A. Thompson, Jr., Strategies for Staying Cost Competitive, Harvard Business Review, 62(1) (1984), 110-117. In fairness, fast food automation has been around since the $19^{\text {th }}$ Century. Angelika Epple, The "Automat". A History of Trechnological Transfer and the Process of Global Standardization in Modern Fast Food around 1900, 7(2) Food \& History 97-118 (2009) (discussing the restaurant chain "Automat" which opened its first location in 1986, and noting, "One of its highly unique selling features around 1900 was that no waiters were to be seen in the guest room. The Automat of that time was — at first sight — operated by vending machines only. 'You absolutely help yourself' was one of its most prominent marketing slogans." Id at 99. The Automat's technology transferred around the U.S. and Europe and eventually developed into the world's largest restaurant chain: Horn \& Hardart. Id at 97.

${ }^{41}$ See, Simon Neville, McDonald's ties nine out of 10 works to zero-hours contracts, The Guardian, Aug. 5, 2013, <www.theguardian.com/business/2013/aug/05/mcdonalds-workers-zero-hour-contracts> (noting that 90\% of McDonald's UK workers have no guaranteed hours); see also, Stephanie Strom, McDonald's Introduces Screen Ordering and Table Service, The New York Times, Nov. 17, 2016, <www.nytimes.com/2016/11/18/business/mcdonalds-introduces-screen-ordering-and-table-service.html> (reporting the cost of purchasing and installing eight touch order screens is $\$ 56,000$ ).

42 Julia Limitone, Fmr. McDonald's USA CEO: \$35K Robots Cheaper Than Hiring at \$15 Per Hour, Fox Business, May 24, 2016 <www.foxbusiness.com/features/2016/05/24/fmr-mcdonalds-usa-ceo-35k-robots-cheaper-than-hiring-at-15per-hour.html >. He further claims that a $\$ 15$ minimum wage results in $\$ 30,000$ a year for a full-time employee.

43 Ed Rensi, The Ugly Truth About A \$15 Minimum Wage, Forbes, Apr. 25, 2016, <www.forbes.com/sites/realspin/2016/04/25/mcdonalds-minimum-wage-reality/\#2c7fa78058bb>. Automated cashiers are already the "norm" in European countries with high labor costs, and McDonalds is now experimenting with selfserve McCafe kiosks. Id.

${ }^{44}$ Carl Benedikt Frey and Michael Osborne, Technology at Work: The Future of InNOVATION AND EMPloymEnT (2015) at 7 <www.oxfordmartin.ox.ac.uk/downloads/reports/Citi_GPS_Technology_Work.pdf>.

${ }^{45}$ See, e.g., Erik Brynjolfsson and Andrew McAfee, The SeCond MACHINE AGE: Work, Progress, AND Prosperity IN A TIME OF BRILLIANT TECHNOLOGIES (2014) at 139. 
will disproportionately affect lower-wage jobs and less educated workers, causing greater economic inequality. ${ }^{46}$

Higher unemployment coupled with growing income inequality is a recipe for social unrest. Worsening inequality exacerbates conflicts and reduces social cohesion. ${ }^{47}$ As Physicist Stephen Hawking has warned, "[e]veryone can enjoy a life of luxurious leisure if the machine-produced wealth is shared, or most people can end up miserably poor if the machine-owners successfully lobby against wealth redistribution. So far, the trend seems to be toward the second option, with technology driving ever-increasing inequality."48

\section{The Ugly}

One of automation's most pronounced, and unappreciated, effects relates to taxes. Under the current tax system, automation produces a substantial reduction in tax revenue. Most of the U.S. government's tax revenue comes from taxes on workers. ${ }^{49}$ By stating that most tax revenue comes from workers, we refer to the aggregate amount of wage tax, income tax and indirect taxes levied on income or wages derived from work at all levels of government. Much of the prior tax policy debate focuses solely on income taxation by the Federal government. Of course, a substantial portion of income subject to Federal income tax arises from work and falls within our definition of worker taxation. However, the tax policy debate has been misleading since wage taxes are also levied on labor income and comprise more than $1 / 3^{\text {rd }}$ of Federal remittances. Likewise, indirect state taxes are levied on workers. Consequently, by replacing employees with

\footnotetext{
${ }^{46}$ Executive Office of the Presidnet Naitonal Science and Technological Committee on Technology, PREPARING FOR THE FUTURE OF ARTIFICIAL INTELLIGENCE at 2 (2016).

47 Oxfam, Wealth: Having it All and Wanting More, Jan. 2015 <policy-practice.oxfam.org.uk/publications/wealthhaving-it-all-and-wanting-more-338125>.

${ }^{48}$ Akshat Rathi, Stephen Hawking: Robots aren't just taking our jobs, they're making society more unequal, Quartz, Oct. 9, 2015 <qz.com/520907/stephen-hawking-robots-arent-just-taking-our-jobs-theyre-making-society-more-unequal/>

49 Office of Management and Budget, The Budget for Fiscal Year 2015, Historical Tables, p. 32-33 <www.whitehouse.gov/sites/default/files/omb/budget/fy2015/assets/hist.pdf>.
} 
machines, the government loses out on employee and employer wage taxes levied by Federal, state, and local taxing authorities. In addition, tax revenue may be further reduced from businesses claiming accelerated tax depreciation on capital outlays for machines and from other tax incentives related to indirect taxation, such as sales tax or value-added tax (VAT) exemptions. ${ }^{50}$

\section{History of the Automation Scare}

Fears of the consequences of automation have been expressed since the industrial revolution. ${ }^{51}$ In 1772, the writer Thomas Mortimer objected to machines, "which are intended almost totally to exclude the labor of the human race."52 In 1821, the economist David Ricardo argued that automation would result in inequality, and that, "substitution of machinery for human labour is often very injurious to the interests of the class of labourers ... [It] may render the population redundant and deteriorate the condition of the labourer." 53 In 1839 , the philosopher Thomas Carlyle more poetically wrote, "[t]he huge demon of Mechanism smokes and thunders, panting as his great task, in all sections of English land; changing his shape like a very Proteus; and infallibly, at every change of shape, oversetting whole multitudes of workmen, as if with the waving of his shadow from afar, hurling them asunder, this way and that, in their crowded march and course of work or traffic; so that the wisest no longer knows his whereabout[s]." ${ }^{, 54}$

\footnotetext{
${ }^{50}$ See Part III, infra.

${ }^{51}$ For that matter, broader social issues related to automation have been discussed about since Aristotle's time. See, e.g., Johannes Hanel, ASsessing InduCED TeChNOLOGY: SOMBART'S UndERSTANDING OF TECHNICAL CHANGE IN THE HISTORY OF ECONOMICS (2008) at 91 (noting Aristotle's hope that machines could occupy the place of slaves in a utopian society.)

52 Thomas Mortimer, LECTURES ON THE ELEMENTS OF COMMERCE, POLITICS AND FINANCES (1801) at 72.

${ }^{53}$ David Ricardo, ON THE PRINCIPLES OF POLITICAL ECONOMY AND TAXATION (1821) at 283-284. "I am convinced, that the substitution of machinery for human labour, is often very injurious to the interests of the class of laboure." Id.

54 Thomas Carlyle, The Works of Thomas Carlyle (2010) at 142. Thomas Carlyle called the Industrial Revolution, "a mechanical age." Id. Carlyle wrote that technology was causing a "mighty change" in their "modes of thought and feeling. Men are grown mechanical in head and in heart, as well as in hand." Id.
} 
The Industrial Revolution even gave birth to a social movement and group, protesting the use of new technologies: the Luddites. ${ }^{55}$ Luddites were primarily English textile workers who objected to working conditions in the $19^{\text {th }}$ Century. They believed that automation threatened their livelihoods, and they were opposed to the introduction of industrial machinery. ${ }^{56}$ Some Luddites engaged in violent episodes of machine breaking, in response to which the English government made machine-breaking a capital offense. ${ }^{57}$

The Luddite Movement died out, but automation concerns persisted throughout the $20^{\text {th }}$ century, often flaring during times of rapid technological progress. ${ }^{58}$ For instance, the debate was revitalized in the 1950s and 1960s with the widespread introduction of office computers and factory robots. ${ }^{59}$ In his 1960 election campaign, John F. Kennedy suggested that automation offered, "hope of a new prosperity for labor and a new abundance for America," but also that it "carries the dark menace of industrial dislocation, increasing unemployment, and deepening poverty." 60

Despite these concerns, technological advances have often resulted in overall job creation. The computer eliminated jobs, but created jobs for working with information created by computers. The automobile eliminated jobs, but created jobs in the motel and fast-food industries. The tractor and other agricultural advances eliminated jobs, but drove job growth in other areas of the

55 See, Richard Conniff, What the Ludites Really Fought Against, Smithsonian Magazine, Mar. 2011 <www.smithsonianmag.com/history/what-the-luddites-really-fought-against-264412/?page=2>.

${ }^{56}$ The National Archives, Luddites <www.nationalarchives.gov.uk/education/politics/g3/>.

57 Id.; see also, Richard Conniff, What the Ludites Really Fought Against, Smithsonian Magazine, Mar. 2011 <www.smithsonianmag.com/history/what-the-luddites-really-fought-against-264412/?page=2>. The "Luddite fallacy" now describes the fear that innovation will have long term harmful labor effects. Id.

${ }^{58}$ In 1924, Mohandas Karamchand Gandhi wrote, "What I object to, is the craze for machinery, not machinery as such. The craze is for what they call labour-saving machinery. Men go on 'saving labour', till thousands are without work and thrown on the open streets to die of starvation." Mohandas K. Gandhi, ALl MEN ARE BROTHERS (1958) at 121.

${ }^{59}$ See, Gladys Roth Kremen, MDTA: The Origins of the Manpower Development and Training Act of 1962, United States Department of Labor (1974) <www.dol.gov/general/aboutdol/history/mono-mdtatext> ("The dawn of the Atomic Age had witnessed the implementation of a new technology that threatened to replace men with machines."); see also, Douglas A. Irwin, OFFSHORING OF AMERICAN JOBS (2009) at 79.

${ }^{60}$ Douglas A. Irwin, OFFSHORING OF AMERICAN JOBS (2009) at 80. 
economy. ${ }^{61}$ In 1900, 41 percent of the workforce was employed in agriculture. ${ }^{62}$ In 2000 , less than 2 percent of the employed labor force worked in agriculture. ${ }^{63}$ Yet this has not translated to a 39\% increase in unemployment. Even as agricultural-based employment and agriculture's relative contribution to the GDP decreased, the productivity of farmworkers skyrocketed and agriculture's absolute contribution to the GDP increased. ${ }^{64}$ Indeed, in each era when concerns have been expressed about automation causing mass unemployment, technology has created more jobs than it has destroyed.

\section{Is This Time Different?}

The automation debate is resurfacing with a vengeance, due to recent advances in artificial intelligence and other automation technologies. Once more, prognosticators have divided into two camps: the optimists who claim there will be a net creation of jobs, and the pessimists who predict mass unemployment and growing inequality. ${ }^{65}$

History favors the optimists. ${ }^{66}$ They argue that technological advances will generate widespread benefits together with overall job creation. They also argue that current unemployment

\footnotetext{
${ }^{61}$ Erik Brynjolfsson and Andrew McAfee, The SeCOnd Machine Age: Work, Progress, AND ProsPerity IN A TIME OF BRILliANT TECHNOLOGIES (2014) at 176.

${ }^{62}$ Carolyn Dimitri, Anne Effland, and Neilson Conklin, The $20^{\text {th }}$ Century Transformation of U.S. Agriculture and Farm Policy, U.S. Department of Agriculture (Jun. 2005) at 2.

${ }^{63} \mathrm{Id}$.

${ }^{64}$ Id. Alston, Julian M., et al. Persistence pays: US agricultural productivity growth and the benefits from public R\&D spending. Vol. 34. Springer Science \& Business Media, 2009.

65 Klaus Schwab and Richard Samans, The Future of Jobs, Preface (2016) <reports.weforum.org/future-of-jobs2016/preface/>; see also Brian Dorini, The End of Work: The Decline of the Global Labor Force and the Dawn of the Post-Market Era, 9 HARV. J.L. \& TECH. 231 (1995) reviewing Jeremy Rifkin, The End of Work: The Decline of the Global Labor Force and the Dawn of the Post-Market Era (New York: New York, G.P. Putnam's Sons, 1995) 233 (“The ranks of the unemployed are swelling with former service sector workers, such as secretaries, receptionists, clerks, and cashiers. These workers are being replaced by what Rifkin calls the silicon-collar workforce: answering machines, scanners, voice and handwriting recognition devices, electronic mail, and inventory control and monitoring devices (pp. 136-43).").

${ }^{66}$ See John Maynard Keynes, ESSAYS IN PERSUASION (1930) at 358-373 (predicting at the combination of technological innovation and capital accumulation will eventually solve the problem of material needs).
} 
may relate more to globalization and offshoring than to technology, and that any future technological unemployment would be, "only a temporary phase of maladjustment." 67

But there is reason to think that this time may be different. ${ }^{68}$ Computers are improving exponentially, and there are fewer limits to what they can do than ever before. Computers can replace low skilled workers and manual laborers as well as white collar workers and professionals in a variety of fields. Computers are already working as doctors, lawyers, artists, and inventors. ${ }^{69}$ All of this is occurring at a time when labor costs are rising and computer costs are declining. In 2012, Vinod Khosla, the co-founder of Sun Microsystems, predicted that diagnostic software would take the jobs of $80 \%$ of physicians in the next 20 years. $^{70}$

While the optimists and pessimists disagree about automation's effects on long term unemployment, both agree it causes short-term job losses and industry specific disruption. During previous times of rapid technological change, it took decades to develop new worker skill sets on a significant scale and to build new job markets. ${ }^{71}$ Although the Industrial Revolution ultimately resulted in net job creation, it also involved periods of mass unemployment and human suffering.

\footnotetext{
${ }^{67}$ See Id.; see also, John Stuart Mill, PRINCIPLES OF POLITICAL ECONOMY (1848) at 97.

${ }^{68}$ Yvonne Stevens, The Future: Innovation and Jobs, 56 Jurimetrics J. 367, 368-9 (2016) ("This time there may be some distinctions requiring widespread and perhaps novel solutions, unlike other periods in history.").

${ }^{69}$ Roger Parloff, Why Deep Learning is Already Changing Your Life, Fortune, Sept. 28, 2016 <http://fortune.com/aiartificial-intelligence-deep-machine-learning/>. Jane Croft, Legal firms unleash office automatons, Financial Times, May 16, 2016, <www.ft.com/content/19807d3e-1765-11e6-9d98-00386a18e39d (discussing various software programs that can outperform attorneys and paralegals in document review). $C$ f. Dana Remus and Frank S. Levy, Can Robots Be Lawyers? Computers, Lawyers, and the Practice of Law, Dec. 30, 2015, available at http://dx.doi.org/10.2139/ssrn.2701092 (arguing that artificial intelligence will refocus rather than replace attorneys). Yonghui Wu, et al., Google's Neural Machine Translation System: Bridging the Gap between Human and Machine Translation, Sept. 26, 2016, available at <arxiv.org/abs/1609.08144. Google now claims its Google Neural Machine Translation system is approaching human-level translation accuracy. Id.

70 Vinod Khosla, Do We Need Doctors or Algorithms? Tech Crunch, Jan. 10, 2012, <techcrunch.com/2012/01/10/doctors-or-algorithms/>.

${ }^{71}$ Klaus Schwab and Richard Samans, The Future of Jobs, Preface (2016) <reports.weforum.org/future-of-jobs2016/preface/>.
} 
In the Automation Revolution, whether there are detrimental long term effects, there will almost certainly be significant short term disruptions. ${ }^{72}$

\section{Automation Social Policy}

It is important that policy makers act to ensure that automation benefits everyone. Our policy goal should be to accommodate and even encourage advances that promote economic value, while redistributing benefits to those negatively affected. During the Industrial Revolution, John Stuart Mill wrote that while automation would ultimately benefit laborers, "this does not discharge governments from the obligation of alleviating, and if possible preventing, the evils of which this source of ultimate benefit is or may be productive to an existing generation [and] there cannot be a more legitimate object of the legislator's care than the interests of those who are thus sacrificed to the gains of their fellow-citizens and of posterity." ${ }^{" 73}$ Or, as the U.S. National Science and Technology Council Committee on Technology argued in 2016, "Public policy can address these risks, ensuring that workers are retrained and able to succeed in occupations that are complementary to, rather than competing with, automation. Public policy can also ensure that the

\footnotetext{
${ }^{72}$ For example, a substantial number of transportation workers are likely to be displaced by self-driving vehicles, and about three percent of the population is employed in the transportation industry. See, Richard Henderson, Industry Employment and Output Projections to 2024, Monthly Labor Review, Dec. 2015; see also, Australian Bureau of Statistics, 2011 Census Community Profiles <http://www.censusdata.abs.gov.au/census_services/getproduct/census/2011/communityprofile/0?opendocument\&nav pos $=220>$. Tesla, for example, plans to make all its vehicles self-driving. BBC News, Tesla to Make All Its New Cars Self-Driving, Oct. 20, $2016<$ http://www.bbc.co.uk/news/technology-37711489>. Tesla is only one of many companies developing such technologies. CB Insights, 33 Corporations Working on Autonomous Vehicles, Aug. 11, 2016, https://www.cbinsights.com/blog/autonomous-driverless-vehicles-corporations-list/; see also, CB Insights, Investment Into Auto Tech On Pace To Break Annual Records, Jul. 14, 2016 <https://www.cbinsights.com/blog/auto-techfunding-h1-2016/>. Elon Musk, the CEO of Tesla, has even claimed that self-driving cars will be so much safer than human drivers, that there will need to be a future ban on human driving. Stuart Dredge, Elon Musk: Self-Driving Cars Could Lead to Ban on Human Drivers, The Guardian, Mar. 18, 2016 <https://www.theguardian.com/technology/2015/mar/18/elon-musk-self-driving-cars-ban-human-drivers>

${ }^{73}$ John Stuart Mill, Principles of Political Economy with some of their Application to Social Philosophy, (1909) at Book I, Chapter VI, Paragraph 13.
} 
economic benefits created by AI are shared broadly, and assure that AI responsibly ushers in a new age in the global economy."74

Efforts to alleviate the harms and share the benefits of automation have focused on education and social benefits. As mentioned earlier, in December 2016, the Executive Office of the President then under Barack Obama issued a report which outlined a three-pronged policy response to AI and Automation: namely, to (i) "[i]nvest in and develop AI for its many benefits", (ii) "[e]ducate and train Americans for jobs of the future", and, (iii) "[a]id workers in the transition and empower workers to ensure broadly shared growth". In terms of education, it is thought that technologically unemployed workers need training (or retraining) to transition to new job types. Historically in the U.S., numerous government and industry programs have been enacted to combat technological unemployment with education. ${ }^{75}$ The nation's first and most sweeping federal training program, the Manpower Development and Training Act of 1962, was signed into law by President Kennedy to train workers unemployed due to technological advances and automation. ${ }^{76}$ More recently, President Obama provided billions of dollars to fund worker training in part to address technological unemployment. ${ }^{77}$ More ambitiously, he proposed a plan to make two years of

\footnotetext{
${ }^{74}$ Executive Office of the Presidnet Naitonal Science and Technological Committee on Technology, PREPARING FOR THE FUTURE OF ARTIFICIAL INTELLIGENCE (2016) at 2.

75 Of particular interest, "the Armour Meat Packing Company created a special "automation fund" for retraining purposes. The company paid a 14-cent levy into the fund, established in 1959, for every 100 tons of meat shipped, up to $\$ 500,000$, to pay for retraining operations." <www.dol.gov/general/aboutdol/history/mono-mdtatext.

${ }^{76}$ Gladys Roth Kremen, MDTA: The Origins of the Manpower Development and Training Act of 1962, United States Department of Labor (1974) <www.dol.gov/general/aboutdol/history/mono-mdtatext>. Also of note, a year earlier, the Office of Automation and Manpower was created at the Department of Labor to anticipate technological change and create occupational guidance. General Order, April 20, 1961, Hist. Ofce.; Press Release, April 20, 1961, Hist. Ofce. For extensive reviews of automation issues in the 1960s, see generally, <onlinebooks.library.upenn.edu/webbin/book/lookupname?key=United\%20States. $\% 20$ Office $\% 20$ of $\% 20 \mathrm{Manpower} \% 2$ C\%20Automation\%20and\%20Training>. Elliot Aronson, Office of Manpower, Automation and Training: Unemployment and retraining; an annotated bibliography of research (1965); see also James L. Sundquist, POLITICS AND POLICY: THE EISENHOWER, KENNEDY, AND JOHNSON YEARS (1968) at 77.

77 See, The While House Office of the Press Secretary, FACT SHEET: President Obama Proposes New 'First Job' Funding to Connect Young Americans with Jobs and Skills Training to Start Their Careers, Feb. 4, 2016 <www.whitehouse.gov/the-press-office/2016/02/04/fact-sheet-president-obama-proposes-new-first-job-fundingconnect-young.
} 
community college free for "responsible students" in his 2015 State of the Union Address, although this proposal was never adopted. ${ }^{78}$ It remains to be seen how President Trump and the current Republican Administration will address these issues.

As the third prong of President Obama's 2016 strategy report notes, social benefit investments are also critical. The report advocates strengthening the social safety net through greater investments in programs such as unemployment insurance and Medicaid. It also proposes the creation of new programs for wage insurance and emergency aid. ${ }^{79}$ In addition, it argues for building a $21^{\text {st }}$ century retirement system, expanding health care access, and increasing worker bargaining power. ${ }^{80}$

Revitalized concerns about technological unemployment have breathed new life into an old social benefit proposal—guaranteed minimum income. ${ }^{81}$ The basic idea is that the government would provide a fixed amount of money to its citizens regardless of their situation. This has been implemented numerous times on a relatively small scale, most recently in Finland. ${ }^{82}$ In 2017 , Finland began a pilot program to give about $\$ 600$ per month to 2,000 unemployed citizens, with no other requirements. ${ }^{83}$ Proponents argue this will reduce unemployment, poverty, and disincentives for the unemployed to work (as under conventional unemployment schemes recipients generally

\footnotetext{
${ }^{78}$ John Morgan, Barack Obama free community college plan backed by $\$ 100 m$ funding, Times Higher Education, Apr 27, 2016 <www.timeshighereducation.com/news/barack-obama-free-community-college-plan-backed-by-one-hundredmillion-dollar-funding >.

${ }^{79}$ Executive Office of the President, ARtificial IntelligenCE, Automation, AND the ECONOMy (2016) at 3.

${ }^{80} I d$.

${ }^{81}$ It was proposed during the Industrial Revolution by Charles Fourier, and then later Joseph Charlier, before being adopted by John Stuart Mill. Philippe Van Parijs, A Basic Income for All, Boston Review, Obt. 1, 2000 <bostonreview.net/forum/ubi-van-parijs>. Mill proposed, "a certain minimum is first assigned for the subsistence of every member of the community, whether capable or not of labour." Id.

82 Whitney Mallett, The Town Where Everyone Got Free Money, Motherboard, Feb. 4, 2015 <motherboard.vice.com/read/the-mincome-experiment-dauphin>.

${ }^{83}$ Kevin Lui, Finland is Giving Nearly $\$ 600$ a Month to 2,000 Jobless Citizens, No Questions Asked, Fortune, Jan. 3 , 2017 <amp.timeinc.net/fortune/2017/01/03/finland-universal-basic-income-experiment/?source=dam>. It is also worth noting, that the U.S. has operated a guaranteed basic income since 1999. The Alaska Permanent Fund pays each person who has lived the past year in Alaska \$1,680. Philippe Van Parijs, A Basic Income for All, Boston Review, Obt. 1, 2000 <bostonreview.net/forum/ubi-van-parijs>.
} 
lose their unemployment benefits after returning to work). It might also encourage education by providing support for a period of training. Critics have argued that a guaranteed minimum income will encourage recipients to remain unemployed and discourage additional education. In any case, Finland plans to eventually replace earnings-based insurance benefits with a basic income. ${ }^{84} \mathrm{Y}$ Combinator, the Silicon Valley startup incubator, has plans to launch a similar private program in Oakland, California. ${ }^{85}$

Improving education and social benefit systems will not be easy. Liberals and conservatives alike can agree on the desirability of improving worker training as it will enlarge the productive labor force, but "[d]elivering this education and training will require significant investments." 86 Enhancing the social benefit system will also require significant investment, but such a goal is even more challenging because liberals and conservatives generally disagree that enhanced benefits are a desirable aim. ${ }^{87}$

That automation creates a need for greater government investment is well known, but what has so far been largely ignored in the automation debate is that automation will make it far more difficult for the government to make investments once tax revenues are reduced.

\footnotetext{
${ }^{84}$ Kevin Lui, Finland is Giving Nearly $\$ 600$ a Month to 2,000 Jobless Citizens, No Questions Asked, Fortune, Jan. 3, 2017 <amp.timeinc.net/fortune/2017/01/03/finland-universal-basic-income-experiment/?source=dam>.

${ }^{85}$ Chris Weller, The inside story of one man's mission to give Americans unconditional free money, Business Insider UK, Jun. 27, 2016 <uk.businessinsider.com/inside-y-combinators-basic-income-project-2016-6?r=US\&IR=T> .

${ }^{86}$ Executive Office of the President, Artificial IntelligenCe, AutOmation, AND THE ECONOMY (2016) at 3.

${ }^{87}$ Stevens at 373 ("One of the most commonly considered government payout schemes is what is referred to as a basic income guarantee. Generally speaking, Basic Income Guarantee is a monetary government-backed and issued guarantee such that all adults have access to an amount of money necessary to meet basic needs."). President Richard Nixon once proposed a guaranteed basic income of about $\$ 10,000$, adjusted for inflation, for families of four. This proposal, the Family Assistance Plan, passed through the House before it was voted down by Senate Democrats. Whitney Mallett, The Town Where Everyone Got Free Money, Motherboard, Feb. 4, 2015 <motherboard.vice.com/read/the-mincomeexperiment-dauphin>.
} 


\section{Current TAX Policies FAVOR Automation}

\section{Introduction}

Worker automation is often thought of as a matter of efficiency, where efficiency refers to the ratio of useful output to total input. ${ }^{88}$ For example, if a machine and a person create the same output, but the machine is less expensive, then automation generates cost savings and improves efficiency. ${ }^{89}$ If a robot costs a firm $\$ 40,000$ a year and a human worker costs $\$ 45,000$ a year, with both workers producing the same output, the firm would yield a $\$ 5,000$ annual cost savings by automating.

However, it may also be the case that the robot costs more than a human worker before taxes, and only becomes cheaper on a post-tax basis. For instance, the capital outlay for the robot, which includes money spent to acquire, maintain, repair, or upgrade fixed or capital assets such as robots, together with the costs for operating the robot (electricity, etc.), might be estimated at $\$ 50,000$ over some period, whereas the wages and other costs associated with an employee (healthcare, retirement funding, etc.) might be $\$ 45,000$ over the same period. The fact that the robot may be associated with tax benefits that do not apply to human workers may reduce the cost of the robot to $\$ 40,000$. A firm using a rational cost-based decision model would choose to automate and realize the machine's tax benefit. In this example, tax policy has rendered the robot a more efficient worker. In simple terms, the heavy relative taxation of the living worker drives the firm toward automation to generate a tax savings.

\footnotetext{
${ }^{88}$ Expressed mathematically, efficiency " $\mathrm{r}$ " is equal to the amount of useful output ("P") divided by the amount ("C $\mathrm{C}$ ") of resources consumed: $\mathrm{r}=\mathrm{P} / \mathrm{C}$.

${ }^{89}$ Stevens at 373 (“Technology is very attractive to owners of capital. Machines require no pay, benefits, sick leave, vacation, lunch breaks, or weekends off. They are less prone to err and are more productive than human beings. In a race for the same job, it is therefore difficult for humans to compete with machines.").
} 
The tax system is not "neutral" as between work performed by robots versus people. ${ }^{90}$ Automation provides several major tax advantages. These include avoidance of employee and employer wage taxes levied by Federal, state, and local taxing authorities, benefits from claiming accelerated tax depreciation on capital costs for automated workers, and indirect incentives for machine or automated workers. Any outputs produced by human labor are thus effectively penalized under the tax system compared to outputs produced by capital. ${ }^{91}$ In fact, as described below, automated workers are taxed less than human workers at both the employer and employee level.

\section{Avoiding Employee and Employer Wage Taxes Via Automation}

Wage taxes as discussed here are levied solely on wages paid to individuals to fund social benefit programs including social security, Medicare and Medicaid. Presently in the United States, the employer and employee pay matching amounts totaling $12.4 \%$ of an employee's salary, plus matching Medicare payments totaling 2.9\% (applied on the first \$127,200 of earnings), plus an additional 0.9\% Medicare surcharge (applied on earnings over \$200,000). ${ }^{92}$ Many states and localities also levy wage taxes that apply in addition to the Federal levies. ${ }^{93}$

90 The analysis of the "neutrality" of taxation is a common practice in the field of taxation. See Peggy Richman (Musgrave), Taxation of Foreign Investment Income: An Economic Analysis (Baltimore, MD: The Johns Hopkins Press, 1963) in Peggy Musgrave, "Tax Policy in the Global Economy”, Selected Essays (Elgar, 2002) (introducing the term "capital export neutrality").

${ }^{91}$ William Meisel, The Software Society, Cultural and Economic Impact (New York: Trafford, 2013), 220 ("An automation tax described as a payroll tax on computers conveys the basic concept. It helps level the playing field. The automation tax serves two purposes: (1) it provides an incentive for a company to create jobs by means such as investing in human-computer synergy; and (2) it proves governmental revenues that, properly used, can create more consumption and thus boost the economy.").

92 Internal Revenue Code $\S \S 3101(a), \S 3111(a) ; \S 3102(a) ; \S 3111(a) ; \S 3121(a)(1) ; \quad$ Internal Revenue Service, <www.irs.gov/taxtopics/tc751.html>; see also Richard Winchester, The Gap in the Employment Tax Gap, 20 STAN. L. \& POL'Y REV. 127, 132 (2009) ("The tax imposed by FICA has two components. The first is the old-age, survivors, and disability insurance component, often referred to as OASDI... that constitute "wages" from employment. One half of the tax is deducted from the employee's compensation. The employer pays the other half. This component of the FICA tax is earmarked to cover social security benefits. There is a limit on the amount of wages that can be taxed...The contribution and benefit base is adjusted each year to reflect increases in average wages of the U.S. economy.”).

${ }^{93}$ For an explanation of the US states that levy sales taxes, see, Scott Drenkard and Nicole Kaeding, State and Local Sales Tax Rates in 2016, Tax Foundation, Mar. 9, 2016 <taxfoundation.org/article/state-and-local-sales-tax-rates-2016>. For an explanation of EU tax policy including the VAT, see, European Parliament (2015), "Tax Policy in the EU" 


\section{Tax Benefit from Accelerated Tax Depreciation on Capital Outlays for Automated Workers}

Tax depreciation refers here to the deduction (a reduction in the tax base) claimed by the firm in respect to capital outlay for automated workers. Deductions for capital outlays for robotic equipment will allow the firm to reduce its tax base over time, which reduces the amount of tax that is payable. Of course, wages paid to individuals are also tax deductible, but the timing of the deduction works differently for robot and human workers, and this may have a significant effect on a firm's tax burden.

An accelerated tax deduction means that the deduction may be claimed earlier than its actual economic depreciation (the reduction in the value of an asset over time). ${ }^{94}$ For example, assume a robot has a total capital cost of $\$ 100,000$ and 7 years of useful life, while an employee has a total wage cost of $\$ 100,000$ over 7 years. If accelerated depreciation for capital is available, ${ }^{95}$ the firm may be able to claim a large portion of the $\$ 100,000$ depreciation as a tax deduction in year 1 rather than pro-rata over 7 years. ${ }^{96}$ For instance, the firm might claim tax depreciation for an automated worker of $\$ 50,000$ in year $1, \$ 30,000$ in year $2, \$ 10,000$ in year 3 , and in diminishing amounts to year 7 . By contrast, wage taxes must be deducted as paid (i.e., $1 / 7^{\text {th }}$ in each year). In

\footnotetext{
<www.europarl.europa.eu/.../2015/.../EPRS_IDA(2015)549001_EN.pdf.

${ }^{94}$ Yoram Margalioth, Not a Panacea for Economic Growth: The Case of Accelerated Depreciation, 26 VA. TAX REV. 493, 494-5, 499 (2007) ("Accelerated depreciation policy can be traced back to an influential 1953 paper by Evsey Domar... [T] he Harrod-Domar model, predicting that Gross Domestic Product (GDP) was proportional to the number of machines; namely, that investment is the key to growth... A later model, developed by Noble Laureate Robert Solow between 1956-57, points out that the Harrod-Domar model cannot explain sustained growth. Solow showed that as capital per worker increases, the marginal productivity of capital declines until the capital-labor ratio approaches a steady-state level. At that point, savings... are just sufficient to replace worn out machines and equip new workers (assuming population growth), so productivity growth is zero.") citing Evsey D. Domar, Capital Expansion, Rate of Growth, and Employment, 14 ECONOMETRICA 137 (1946); Roy F. Harrod, An Essay in Dynamic Theory, 49 ECON. J. 14 (1939); but see Robert M. Solow, A Contribution to the Theory of Economic Growth, 70 Q. J. ECON. 65 (1956); Robert M. Solow, Technical Change and the Aggregate Production Function, 39 REV. ECON. \& STAT. 312 (1957).

95 Margalioth at 505 ("For tax reporting purposes, the Code allows the use of much more accelerated depreciation methods than the straight-line method.").

${ }^{96} I d$. at 505 ("The vast majority of U.S. corporations use a depreciation method called 'straight-line' for financial reporting purposes. According to the straight-line depreciation method, annual depreciation is calculated by subtracting the salvage value of the asset from the purchase price and dividing this number by the estimated useful life of the asset. The outcome is equal periodical deductions throughout the asset's useful life. If the asset in the above example is depreciated under the straight-line method, its $\$ 1000$ cost is allocated uniformly over its useful life period of five years, resulting in \$200 of depreciation deduction each year.”).
} 
this case, a present value benefit will accrue from claiming accelerated tax deductions for automated workers relative to the pro-rata tax deductions for employee wages, even where the $\$ 100,000$ capital outlay is paid up-front. ${ }^{97}$ This is possible because the present value of the accelerated tax deduction on capital investment is greater than the discounted value of the return the firm could make by investing the free cash held on its balance sheet.

Tax depreciation (whether accelerated or not) is also generally available even where the actual rate of inflation is equal to or greater than the economic depreciation. ${ }^{98}$ Inflation here refers to the rate at which the general level of prices for goods and services is rising such that it would cost more to build the same robot next year than it costs today. The issue becomes significant where, as in the prior example, it was presumed for tax purposes the robot wears out after 7 years, but it turns out the robot actually increases in nominal value rather than wearing out. An incremental tax benefit thus accrues where the rate of inflation is higher than the rate of the actual diminishment in economic value, and where the nominal (or inflationary) difference is never recaptured in the tax system. In the corporate setting this recapture of tax book to inflation difference would only accrue on the disposal of the asset, which rarely occurs. The same principle applies to commercial real estate, where tax depreciation is allowable on an asset that is actually increasing (not decreasing) in nominal value over time, and the difference is not adjusted for tax purposes.

\footnotetext{
${ }^{97}$ Most large corporations have significant cash accumulations and do not need to borrow funds (and pay interest) to make capital expenditure on automation. Notably, if corporate borrowing is required to fund capital expenditure, then the present value calculation gets more difficult since the interest paid will also be tax deductible, however interest will become payable. In summary, accelerated tax depreciation yields an economic benefit where the firm has balance sheet cash earning a low rate of return which it can instead deploy to yield tax deductions on an accelerated basis.

${ }^{98}$ Margalioth at 508 ("In times of inflation, recovery of the nominal cost of investment is not sufficient to match income and expenses. Because of inflation, the income generated by the asset is expressed in a larger number of dollars though it has the same purchasing power.").
} 
Finally, firms can use accounting "tricks" to report a tax benefit to earnings due to automation, which they may want to do for a variety of reasons, such as making the company look more attractive to potential investors. Where tax depreciation is accelerated relative to book depreciation (the amount reported on financial statements), a firm may generally claim a profit (or earnings benefit) to reported earnings from the tax benefit. ${ }^{99}$ Thus, a large corporation enjoys a book benefit to reported financial earnings from the differential in depreciation periods. Any firm seeking to accelerate reported earnings could use automation to achieve such a timing benefit. This increase to reported earnings may be an even more significant motivation for large firms to automate than a cash tax savings.

\section{Indirect Tax Incentives for Automated Workers}

The indirect tax system also benefits automated workers at the firm level. Indirect taxation refers to taxes levied on goods and services rather than on profits; the primary examples are the Retail Sales Tax (RST) levied by states and municipalities in the United States and the Value Added Tax (VAT) in most other countries. Employers are thought to bear some or all the incidence of indirect tax, as worker salaries and retirement benefits must be increased proportionately to offset the indirect tax. In the case of automated workers, however, the burden of indirect taxes is entirely avoided by the firm. ${ }^{100}$ In general, business expenditures for capital assets such as machinery are exempt from indirect taxation, or yield a deduction for RST or VAT. ${ }^{101}$

\footnotetext{
99 Id. at 505 ("Accounting for depreciation is also required for financial reporting purposes. Generally accepted accounting principles (GAAP) require the depreciation of the (depreciable) cost of income generating assets, usually, tangible assets. The cost has to be allocated among accounting periods on a systematic and rational basis that reflects the use of the asset in the revenue generating process over the asset's operational life.").

100 The capital assets comprising automated workers might be subject to property taxation by some local jurisdictions as business personal property. However, such personal property taxation is often successfully mitigated by tax planning or with tax waivers by local jurisdictions and municipalities negotiated by municipalities. Furthermore, human employees also engender some degree of attached personal property (e.g., office fixtures, personal computers) which are also subject to personal property taxation.

${ }_{101}$ See John Mikesell, Sales Tax Incentives for Economic Development: Why Shouldn't Production Exemptions Be
} 


\section{Automation Reduces Tax Revenue}

The share of the tax base borne by labor is increasing. It is approximately $3 / 4^{\text {ths }}$ of the total tax base in the United States, and perhaps is significantly greater. ${ }^{102}$ In the European Union, high rates of wage taxation are levied in addition to VAT, which is also thought to burden workers, this time in their role as consumers. Moreover, capital taxation is trending sharply downwards in nearly all jurisdictions. Corporate taxation now comprises less than $9 \%$ of the overall tax base in the United States. This is roughly one-half of its respective share compared to prior decades. ${ }^{103}$ If anything, corporate tax rates are predicted to decrease further given the Republican control of both houses of Congress and recent political events centered on the tax policy objectives of President Trump. ${ }^{104}$ In Europe, lower taxation of capital is welcomed as a means of international tax competition. $^{105}$

Worker taxation is different from corporate taxation in several respects. Tax avoidance planning is not generally available to wage earners. For instance, an employee cannot use transfer pricing techniques to shift earned income into a 0\%-taxed entity in the Cayman Islands. Also, wage earnings are not subject to potential deferral, meaning labor income is taxed currently whereas capital may be taxed upon future disposition of an asset. Human capital is also not depreciable, so a person does not typically get a tax deduction for education or medical costs, at least not up to the full amount of the investment. ${ }^{106}$ By contrast, machinery or other equipment

General?, 54:3 NAT'L TAX J. 557 (200X)

102 OMB (2015); Internal Revenue Service, Data Book Statistics www.irs.gov/uac/SOI-Tax-Stats-Collections-andRefunds,-by-Type-of-Tax-IRS-Data-Book-Table-1.

${ }^{103}$ See Lester Snyder \& Marianne Gallegos, Redefining the Role of the Federal Income Tax: Taking the Tax Law "Private" Through the Flat Tax and Other Consumption Taxes, 13 AM. J. TAX POL'Y 1 (1996).

104 The Trump tax plan calls for a reduction in the corporate tax rate and the partial elimination of deferral on foreign earnings of US multinationals, see: Alan Cole, Details and Analysis of the Donald Trump Tax Reform Plan, September 2016 <taxfoundation.org/sites/taxfoundation.org/files/docs/TaxFoundation_FF528_FINAL3.pdf>.

${ }^{105}$ Meisel at 223 ("What numbers are used in the ratio of revenues to employees? I recommend using revenues generated within the taxing country and employees within the country in the ratio.").

${ }^{106}$ For the US incentives with an election for deduction or credit on higher education costs see: Internal Revenue Code, Section 25A (Hope and Lifetime Learning Tax Credits). 
yields an immediate and ongoing tax deduction to a firm until the equipment's tax basis is reduced to zero. Workers are additionally subject to various forms of indirect taxation, particularly in Europe and in states or local jurisdictions, whereas business machinery is often exempted from RST and VAT.

If corporate taxes decline as a share of the tax base while the overall level of taxation holds constant, other types of taxation may increase to cover the difference. While a government may choose to increase borrowing or decrease spending, over the long term this would be expected to have negative economic effects. As a policy goal, worker automation should be engineered to have zero-sum effects to the economy, in which the taxation of workers and capital within the workforce might be expected to increase as some workers are eliminated and replaced by automation.

\section{TAX POLICY OPTIONS FOR AN AUTOMATION TAX}

The current tax system is designed to principally tax human workers and not robot workers. All else being equal, this creates a situation in which firms prefer robots since substantially less tax per output is accrued or remitted in respect of an automated worker. At the same time, the automation of large segments of the labor force threatens long-term fiscal solvency because of the potential reduction in tax collections.

A major automation policy issue is therefore how to adjust the tax system to be at least neutral as between robot and human workers. In doing so, it is important to consider that capital investment of any kind (including for robots) is thought to be beneficial to economic growth. Nations engage in tax competition to draw capital into their jurisdictions. Any disallowance of capital deduction would serve as a disincentive to investment and would, theoretically, be economically undesirable. For example, if only one taxing jurisdiction disallowed tax deductions for automated workers, multinational firms might shift their capital investments to other 
jurisdictions. ${ }^{107}$ It is therefore important to consider economic efficiency in creating an automation neutral tax system. ${ }^{108}$ Several possibilities exist.

\section{Disallowance of Corporate Tax Deductions for Automated Workers}

A first option is to attempt to disallow the respective corporate income tax deductions for capital investment that give rise to the automation tax benefit. The basic idea is to reverse each of the tax benefits accruing in the case of worker automation in relation to avoidance of levy of wage taxes, accelerated or timing difference of deductions, and indirect tax benefits.

To begin with Federal income taxation, the disallowance of tax preferences upon some threshold of income level is a common practice in the Internal Revenue Code and is often referred to as a "phase-out." 109 In practice, this means that a tax preference is reduced based on some eligibility criteria. For instance, student loan interest is deductible, but not for individuals with more than $\$ 80,000$ in modified adjusted gross income (MAGI) $\left(\$ 160,000\right.$ for joint filers). ${ }^{110} \mathrm{~A}$ new code provision could be designed with a similar "phase out," where depreciation or other expenses related to automated workers would be disallowed based on a reported level of automation. For example, firms with high levels of worker automation could have their tax depreciation automatically reduced beyond a certain threshold. The Treasury Department would need to craft

\footnotetext{
${ }^{107}$ The shift would be from one high-tax jurisdiction to another high-tax jurisdiction to claim the deduction's full value, however, rather than a shift into tax havens with a $0 \%$ corporate tax rate, where the capital tax deductions for automated workers would not have any value (i.e., the value of a tax deduction in a $0 \%$ tax jurisdictions is 0 ). Thus, multinational firms should not be expected to make capital investment in robots in tax havens where the value of deductions is zero, especially where transfer pricing strategies are available to shift income arising from the automated workers.

${ }^{108}$ Meisel at 226 ("There are other alternatives using the tax code. One option suggested by Martin Ford in The Lights in the Tunnel is modification of the payroll tax, a tax that discourages hiring people and encourages automation since it makes the use of people more expensive. He suggests a reform of the tax system where we get away from taxing based on workers to reduce the disincentive to hiring.") citing Martin Ford, The Lights in the Tunnel: Automation, Accelerating Technology and the Economy of the Future (New York: Createspace, 2009).

${ }^{109}$ See generally Emmanuel Saez, Do Taxpayers Bunch at Kink Points? 2 AM. ECON. J. ECON POL'Y 180 (2010).

${ }^{110}$ Internal Revenue Service, Student Loan Interest Deduction <https://www.irs.gov/publications/p970/ch04.html>.
} 
detailed regulations and criteria to identify the threshold and to measure the level of automation required to trigger the disallowance.

In respect of indirect taxation, a simpler solution may be possible. Indirect tax preferences for capital outlay in respect to automated workers could be disallowed outright at the state level. Thus, for example, where the firm attempts to claim an RST/VAT exemption or refund for tax payments made on behalf of automated workers, this would not be permitted.

These measures alone will not be adequate, however, since the disallowance of corporate income tax deductions will not adequately address the decline in the wage tax base used to fund social insurance benefits.

\section{Levy of an Automation Tax}

A second option is to levy an incremental Federal "Automation Tax" to the extent workers are laid-off or replaced by machines. ${ }^{111}$ A similar system is in place with respect to unemployment compensation in many states where worker lay-offs are tracked and employers are given corresponding ratings. Employers must pay into an unemployment insurance scheme based on their ratings, so a business which has more layoffs pays more in taxes for unemployment insurance. A Federal automation tax could be designed to do essentially the same thing where worker lay-off data could be obtained from the states and then used to levy an additional Federal tax to the extent the Treasury department determined the lay-offs were due to automation.

A drawback to the levy of an additional automation tax is that it would essentially increase the corporate effective tax rate for many firms, and also increase the relative complexity of the tax

\footnotetext{
${ }^{111}$ For a comprehensive discussion of a "telecommuting tax" see: Michael Kraichal, The Chilling Realities of the Telecommuting Tax: Adapting Twentieth Century Policies for Twenty-First Century Technologies, 15 U. PITT. J. TECH. L. \& POL’Y 224 (2015).
} 
system. Economic theory suggests that higher rates and added complexity are negatives in terms of international tax competition. Another drawback is that firms might accelerate lay-offs upon passage (or debate) of the bill prior to implementation to avoid the tax by reducing the number of employees upon the effective date of the law. Accordingly, a retroactive effective date for measurement of employment levels for the automation tax would be a practical necessity.

\section{Grant Offsetting Tax Preferences for Human Workers}

A third option is to attempt to grant offsetting tax preferences for firms that employ human workers for each category of tax benefit. To begin with wage taxation, the tax preference could entail a repeal of the employer contributions to the social security and Medicare systems. The result would be that both human and automated workers would be exempt for the employer in terms of wage taxes—not just automated workers. However, this approach seems unfeasible on political grounds in that it would accelerate the insolvency of the social security system.

In terms of income taxation, an offsetting preference for human workers could be designed as an accelerated deduction for future wage compensation expense (i.e., the firm would get an accelerated tax deduction) to match the accelerated depreciation for automated workers. In terms of indirect taxation typically levied by the states, the contemplated offset would be for indirect taxes not typically levied on wage income. This would constitute an incentive for firms to employ human workers.

\section{Levy of a Corporate Self-Employment Tax}

A fourth option is to increase corporate level taxation for firms that produce outputs without using human labor. The additional taxes would be a substitute amount for social security and Medicare wage taxes avoided by the firm with automated labor. ${ }^{112}$ In part, this is the corollary to

\footnotetext{
${ }^{112}$ Meisel at 222-3 ("Returning to the payroll tax analogy, companies that hire fewer people pay fewer payroll taxes.
} 
the individual self-employment tax where a small-business owner is required to pay monies into the social security system approximating the social security taxes that would be paid on his or her own wages deemed to be paid to self. The corporate self-employment tax would be calculated as a substitute for what employment taxes would have been on the worker and employer if a human worker had continued to perform the work. ${ }^{113}$ The corporate self-employment tax could be calculated based on a ratio of corporate profits to gross employee compensation expense. If the ratio exceeds an amount determined by the Treasury (in reference to industry standards), then backup withholding could apply on corporate profits. The gross amount of the automation tax could be designed to match the wage taxes avoided by the firm with automated workers.

William Meisel has similarly proposed an "automation tax" which he referred to in lay terms as a "payroll tax on computers." 114 This would be similar to the corporate self-employment tax described here. Meisel wrote:

I propose that a national automation tax be based on the ratio of a company's revenues (total sales) to their number of employees... [T] he automation tax should increase as a percentage as the revenue-per-employee [ratio] grows, making it more attractive to create jobs than to replace them with automation... I prefer applying the percentage to revenues... Profits can be manipulated with deductions and other accounting complexities much more than revenues. ${ }^{115}$

The payroll tax in the US helps fund social security, Medicare, and unemployment insurance. In Europe, payroll taxes are even higher than in the US.").

${ }^{113}$ Meisel at 226 ("The automation tax might encourage companies to prefer productivity improvements achieved by using a combination of human and computer capabilities.").

${ }^{114}$ Meisel at 219 ("If software is to take over many jobs, why not have an income tax on software? We could perhaps think of it as a payroll tax on computers.").

${ }^{115}$ Meisel at 221-3. 
Meisel's "automation tax" differs from our proposed corporate self-employment tax in that the former uses a sales ratio as opposed to a profit ratio. A sales ratio is likely unworkable in practice since the tax would prohibitively fall on firms with high sales but low profit margins, such as discounted retailers. Since automation often occurs in the high-tech industry among companies with high profit-margins, it seems preferable that a viable "automation tax" using a ratio to employee expense should be premised on profits, not sales.

\section{Increase the Corporate Tax Rate}

A fifth option would be to significantly increase the corporate tax rate in combination with our earlier proposals. The counter-intuitive advantage of this approach is that higher corporate tax rates increase the relative value of tax deductions for marginal investment. Marginal investment refers to incremental investment made only because of the tax system. ${ }^{116}$ As one of us has explained, “The experienced tax attorney always counsels the client that marginal capital investment is tax deductible." 117 Thus, multinational firms may make capital investment into higher tax jurisdictions in lieu of tax haven jurisdictions partly to claim tax deductions of relatively higher value. Partly for this reason, for smaller and growing firms that are reinvesting profits back into their businesses, the higher rate of corporate tax is not a major disincentive. Ongoing tax deductions will substantially reduce the tax base regardless of the ultimate tax rate to be applied.

The drawbacks to increasing the corporate tax rate are well-known and may be summarized as follows. First, the corporate tax rate might be a signal to firms about the tax climate of a jurisdiction, so higher tax rates could have a negative psychological effect on capital investment decision making. ${ }^{118}$ Second, accelerated tax deductions would be a stronger automation incentive

\footnotetext{
${ }^{116}$ See Bret N. Bogenschneider, The Tax Paradox of Capital Investment, 33:1 J. TAX'N OF INVESTMENTS 59 (2015). ${ }^{117} I d$. at 61 .

${ }^{118} I d$. at $60-1$ ("Any income tax system is designed initially to favor active investors. This is because no matter how high the actual tax rate, it is levied only on what is referred to as "taxable income." Of course, "taxable income" means
} 
with a higher corporate tax rate as the deduction would have greater value. Third, the increase in corporate tax rates would affect all firms even those not engaged in worker automation. Hence, the increase in corporate tax rate option might be viewed as one version of zero-sum analysis, in which tax policy is designed not to allow a shift of the tax burden from capital to other taxpayers.

Further, any increase in corporate tax rates may prompt firms to attempt to shift the tax incidence to workers or consumers. ${ }^{119}$ Finally, increasing corporate tax rates may be politically unfeasible. As Meisel notes in an understated fashion: "Corporations might instinctively fight a corporate tax." 120

\section{Issues in Economic Efficiency Relevant to Automation Tax Policy Proposals}

The tax policy analysis developed here comes from the perspective of average effective tax rates as opposed to solely marginal rates. ${ }^{121}$ Any marginal tax rate methodology excludes an analysis of taxation relative to the overall share of the tax base. For example, technology and pharmaceutical companies often pay a very low average effective tax rate (e.g., less than 10\%) but could also be correctly found to simultaneously have a high marginal effective tax rate (e.g., about $35 \%)$. A corporate taxpayer which pays very little tax relative to its level of taxable income could correctly describe its marginal tax rate as "high." Further, multinational firms do not engage in tax avoidance planning to reduce income which they do not intend to earn. Accordingly, the last dollar of income may nearly always be found to be taxed at a "high" marginal tax rate, even where the average effective tax rate is relatively low. ${ }^{122}$

the amount of profits less deductions. Every tax professional is aware of this feature of an income tax system and counsels the client accordingly.").

${ }^{119}$ Although, firms behave as if they bear the incidence of corporate taxation. Kimberly Clausing, In Search of Corporate Tax Incidence, 65 TAX LAW REV. 433 (2012).

${ }^{120}$ Meisel at 225.

121 The calculation of a marginal tax rate is essentially the theoretical opposite of the calculation of taxation as a percentage of the share of the overall tax base.

${ }^{122}$ For example, a firm may have an overall tax rate of $20 \%$ on all of its earnings, however, with respect to a hypothetical decision of whether to earn incremental income the marginal tax rate might be $35 \%$. 
Economic models of taxation are typically designed by modeling the hypothetical effects of changes in marginal tax rates. ${ }^{123}$ Marginal tax rates again represent incremental changes to the statutory tax rate on the last dollar of income. ${ }^{124}$ For example, a change in the statutory corporate tax rate from $35 \%$ to $30 \%$ would be reflected in economic models premised on marginal rate analysis. The trouble with this form of economic modeling is that its validity relies on the presumption that firm decisions are made based on tax effects on the marginal investment and not based on an average. This approach has major implications for tax policy design as tax cuts to the statutory rate are nearly certain to have a marginal effect even where the firm does not pay a high tax rate overall. Thus, business and investment decisions are presumed not to proceed at the average tax rate for all earned income, but only with respect to incremental tax changes relevant to marginal income.

Other economic modelling proceeds on a marginal effective tax rate basis (i.e., reflecting that corporate taxpayers do not pay the statutory rate). For example, the granting of an additional deduction for manufacturing activity to corporations could reduce the marginal effective tax rate on the last dollar of income from $30 \%$ to $27 \%$ where the statutory rate is $35 \%$. By this method, the firm would be presumed to make an investment decision based on the average tax rate at the margin. Both approaches are distinguishable from analysis using simply an average effective tax rate, which for large corporations is now calculated at approximately $20 \%$ (including permanent deferrals) and trending downward. ${ }^{125}$ However, for many tech companies the effective tax rate is

\footnotetext{
${ }^{123}$ For a discussion of marginal tax rates in economic analysis see: David Madden, The Poverty Effects of a 'Fat Tax' in Ireland, 24 HeALTH ECON. 104, 106 (2015) ("The difficulties associated with non-marginal tax reforms have led a number of analysts to concentrate on marginal tax reforms. This approach has the advantage of not requiring estimates of individual demand and utility functions.").

${ }^{124}$ The US Federal statutory corporate tax rate is 35\%. Internal Revenue Code, Section 11. Various individual US states also levy an incremental state level corporate tax. See <taxfoundation.org/article/state-corporate-income-tax-rates-andbrackets-2016>.

${ }^{125}$ For effective tax rates on multinational firms including the delay in taxation of foreign earnings for US multinationals see: Bret N. Bogenschneider, The Effective Tax Rates of U.S. Firms with Permanent Deferral, 145 TAX NOTES 1391 (2015).
} 
below $10 \%$. At such very low average effective tax rates, it is not clear that economic analysis of marginal effects of tax cuts is a realistic method of tax policy analysis. By such methods, significant macroeconomic benefits can be posited where corporate effective tax rates are reduced from very low levels to even lower levels (e.g., from $2 \%$ to $1 \%$ ), but where it is likely that factors other than marginal taxation are likely to drive firm investment decisions. Also, the positing of economic growth from marginal tax cuts does not consider the effect changes in the composition of the overall tax base, where the taxation of one factor is substantially reduced, namely capital, and the taxation of another factor is increased (or overall borrowing is increased).

In summary, notwithstanding that the statutory corporate tax rate, or marginal corporate effective tax rates, might be correctly described as "high" in the economic theory of taxation, such analysis is also subject to a relative or zero-sum form of analysis, where tax cuts for one party are transferred as tax increases to another party. The average effective tax rate on workers is relatively "high" where all types of taxation are taken into account. ${ }^{126}$ The taxation of workers comprises the bulk of the tax base in the United States and that of most developed countries. As workers are substituted or replaced by automation, follow-on effects are possible not only from the direct reduction in the tax base, but also indirectly where the relative taxes are transferred to other workers in the economy.

\section{Concluding Thoughts}

Automation promises to be one of the great social challenges of our generation. It can benefit everyone, or it can benefit the select few at the expense of the many. Which outcome occurs may have to do with whether policy makers are prepared to make politically challenging decisions about how they choose to deal with automation.

\footnotetext{
${ }^{126}$ See Bret N. Bogenschneider, The Effective Tax Rate of U.S. Persons by Income Level, 145 TAX NotES 117 (2014).
} 
Tax is a critical component of any automation policy. Existing tax policies both encourage automation and dramatically reduce the government's tax revenue. This means that attempts to craft policy solutions to deal with automation will be inadequate if they fail to take taxation into account. In 2017, when Bill Gates proposed taxing automation, he noted that, "[e]xactly how you'd do it, measure it... it's interesting for people to start talking about now." This article has aimed to advance that dialogue. 